\title{
Neuropathogenic Escherichia coli K1 does not exhibit proteolytic activities to exert its pathogenicity
}

\author{
Junaid lqbal ${ }^{1}$, Mehak Rajani ${ }^{2}$, Ruqaiyyah Siddiqui ${ }^{1}$ and Naveed Ahmed Khan ${ }^{1 *}$
}

\begin{abstract}
Background: Proteases are well-known virulence factors that promote survival, pathogenesis and immune evasion of many pathogens. Several lines of evidence suggest that the blood-brain barrier permeability is a prerequisite in microbial invasion of the central nervous system. Because proteases are frequently associated with vascular permeability by targeting junctional proteins, here it is hypothesized that neuropathogenic Escherichia coli K1 exhibit proteolytic activities to exert its pathogenicity.

Methods: Zymographic assays were performed using collagen and gelatin as substrates. The lysates of whole E. coli K1 strain E44, or E. coli K-12 strain HB101 were tested for proteolytic activities. The conditioned media were prepared by incubating bacteria in RPMI-1640 in the presence or absence of serum. The cell-free supernatants were collected and tested for proteases in zymography as mentioned above. Additionally, proteolytic degradation of host immune factors was determined by co-incubating conditioned media with albumin/immunoglobulins using protease assays.

Results: When collagen or gelatin were used as substrates in zymographic assays, neither whole bacteria nor conditioned media exhibited proteolytic activities. The conditioned media of neuropathogenic E. coli K1 strain E44, or E. coli K-12 strain HB101 did not affect degradation of albumin and immunoglobulins using protease assays.

Conclusions: Neither zymographic assays nor protease assays detected proteolytic activities in either the whole bacteria or conditioned media of E. coli K1 strain E44 and E. coli K-12 strain HB101. These findings suggest that host cell monolayer disruptions and immune evasion strategies are likely independent of proteolytic activities of neuropathogenic E. coli K1.
\end{abstract}

Keywords: E. coli K1, Protease, Collagen, Gelatin, Zymography, BSA and IgG

\section{Background}

Proteases hydrolyze peptide bonds of amino acids residues in a polypeptide chain [1]. Given the presence of active residues in their catalytic sites, proteases are classified into six different types including, aspartic-, cysteine-, glumatic-, serine-, threonine- and metalloproteases, among which serine- and metallo-proteases are most abundant in nature [1]. Besides their physiological role, many proteases are involved in pathogenesis of infectious and non infectious diseases. Among

\footnotetext{
* Correspondence: Naveed5438@gmail.com

'Department of Biological and Biomedical Sciences, Aga Khan University, Karachi, Pakistan

Full list of author information is available at the end of the article
}

bacterial infections, two remarkable examples of proteases include lethal factor of anthrax toxin and botulinum neurotoxin produced by Bacillus anthracis and Clostridium botulinum, respectively $[2,3]$. The lethal factor of anthrax toxin is responsible for degradation and inactivation of host cell mitogen-activated protein kinase kinase (MAP2K) [3], whereas Clostridium botulinium produces a powerful neurotoxin protease that impedes acetylcholine release at peripheral nerve ending by cleaving the SNAP-25 protein. SNAP-25 is involved in vesicle fusion and facilitate acetylcholine release from axon endings into the synaptic cleft [2]. Besides the above mentioned bacterial proteases, conserved Lon, Clp, and HtrA bacterial proteases are also believed to be

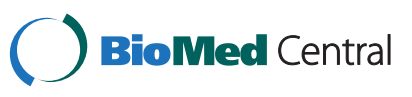



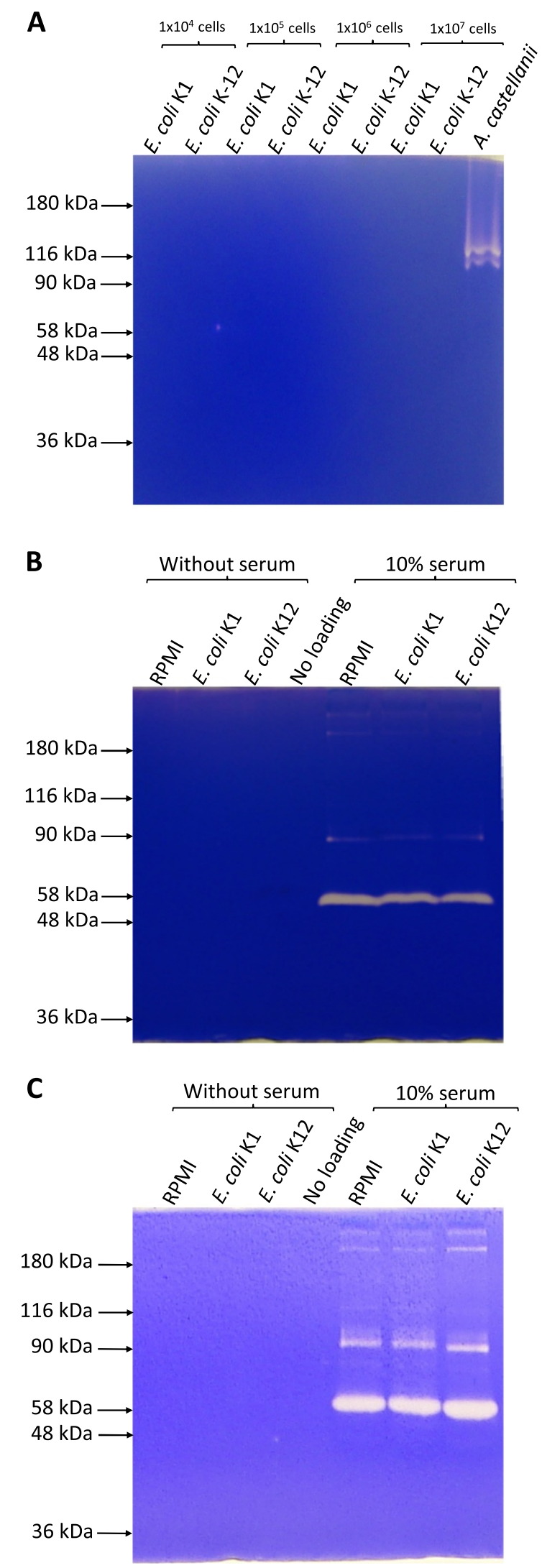

Figure $1 \mathrm{E}$. coli $\mathrm{K} 1$ did not exhibit proteolytic activities in zymography. (A) Neuropathogenic E. coli K1 strain E44 and E. coli K-12 laboratory strain HB101 were grown overnight with shaking under aerobic condition at $37^{\circ} \mathrm{C}$ in RPMI 1640 . Next day the optical density was adjusted to 0.22 for $\mathrm{K} 1$ and 0.35 for $\mathrm{K}-12$ using $595 \mathrm{~nm}$ wavelength yielding approximately $1 \times 10^{8}$ per $\mathrm{mL}$ bacterial c.f.u. Various bacterial counts were mixed with lysis buffer and loaded onto $7.5 \%$ SDS-PAGE gel containing gelatin as substrate, while $A$. castellanii $\left(10^{4}\right.$ cells) was used as a positive control. After electrophoresis, gels were washed for four times with 2.5\% Triton X-100 solution for $30 \mathrm{~min}$ and incubated overnight in developing buffer (50 mM Tris-Cl pH 7.5, 100 mM NaCl, 5 mM CaCl $2,500 \mu \mathrm{M}$ $\mathrm{MgCl}_{2}$ and $2 \mu \mathrm{M} \mathrm{ZnCl}_{2}$ ). Following this incubation, gels were stained with Coomassie Brilliant Blue, destained and finally visualized. (B and C) E. coli $\mathrm{K} 1$ and $\mathrm{K} 12$ were grown overnight with shaking under aerobic condition at $37^{\circ} \mathrm{C}$ in RPMl 1640 with or without $10 \%$ serum fetal calf serum. Next day, cells were removed by centrifugation and cell free conditioned mediums were collected and $10 \mu \mathrm{l}$ of these were loaded along with uninoculated medium on $7.5 \%$ gelatin (B) and collagen $(\mathbf{C})$ substrates zymography gels as described in A. Note that neither whole bacteria nor their conditioned medium degraded gelatin/collagen in zymographic assays tested. The results are representative of three independent experiments.

involved in the virulence of different Gram positive and negative bacteria [4]. Lon and Clp proteases are involved in the regulation of type III secretion system that is responsible for delivering different toxin and virulence factors to host cells. Whereas HtrA, in addition to its protease activity, also has chaperone activity which is involved in the localization and export of different virulence factors from different bacterial pathogens [4].

E. coli $\mathrm{K} 1$ is a leading cause of infant meningitis and sepsis in both developed and developing world. These infections have high mortality rates of $40-50 \%$ and affect 5-50 infants among 100,000 live births and estimated to be responsible for $\sim 50,000$ deaths worldwide per year [5-8]. One reason for such high mortality rate is inadequate understanding of pathogenesis and the pathogen itself. A number of virulence factors including cytotoxic necrotizing factor 1 (CNF1), FimH, outer membrane protein A (OmpA), Ibe proteins, TraJ, and As1A have been identified [9], but the role of proteases in E. coli $\mathrm{K} 1$ pathogenesis have not been studied. Given that proteases are frequently associated with vascular permeability $[1,10]$, here it is hypothesized that the neuropathogenic E. coli $\mathrm{K} 1$ exhibit proteolytic activities to exert its pathogenicity.

\section{Materials and methods}

E. coli $\mathrm{K} 1$ strain $\mathrm{E} 44$, a spontaneous rifampin-resistant mutant of a cerebrospinal fluid isolate of K1encapsulated $E$. coli RS218 (O18:K1:H7) [11] was used as an invasive isolate, while E. coli K-12 strain HB101 was used a non-invasive laboratory isolate in the present study. For routine culturing, both bacteria were grown 
in Luria-Bertani (LB) broth overnight. For zymographic assays, bacteria were grown overnight with shaking under aerobic condition at $37^{\circ} \mathrm{C}$ in RPMI 1640. Next day the optical density was adjusted to 0.22 for E44 and 0.35 for HB101 using $595 \mathrm{~nm}$ wavelength yielding approximately $1 \times 10^{8}$ per $\mathrm{mL}$ bacterial colony forming units (c.f.u.). To determine proteolytic activities, whole cell lysates were prepared by incubating various bacterial counts in $2 \times$ SDS sample buffer without betamercaptoethanol and kept unboiled for $30 \mathrm{~min}$ at room temperature, followed by vortexing. Finally, bacterial lysates were tested for proteases in zymography. For positive controls, Acanthamoeba castellanii lysates were prepared. Briefly, amoebae $\left(10^{4}\right.$ parasites in $\left.10 \mu \mathrm{L}\right)$ were incubated in lysis buffer as above and tested for proteolytic activities in substrate zymography.

To determine the presence of extracellular proteolytic activities, E. coli conditioned media were prepared. To produce conditioned media, E. coli $\mathrm{K} 1$ and $\mathrm{K} 12$ were grown overnight with shaking under aerobic condition at $37^{\circ} \mathrm{C}$ in RPMI 1640 with or without $10 \%$ serum fetal calf serum. The cell-free conditioned media was removed by centrifugation at $10,000 \times g$ for 2 min and $10 \mu \mathrm{l}$ of these were loaded along with uninoculated medium on SDS-PAGE gels containing gelatin and collagen as substrates described below.

For zymographic assays, whole cell bacterial lysates or their conditioned media were mixed (1:1) with sample buffer (containing 4\% sodium dodecyl sulfate (SDS) but without $\beta$-mercaptoethanol) and electrophoresed on
7.5\% SDS-polyacrylamide gel electrophoresis (SDSPAGE) containing gelatin (obtained from bovine skin, Sigma-Aldrich; $1 \mathrm{mg} / \mathrm{mL}$ final conc.) or collagen I (obtained from rat tail, Sigma-Aldrich; $1 \mathrm{mg} / \mathrm{mL}$ final conc.). After electrophoresis, gels were soaked in $2.5 \%$ Triton X-100 (w/v) solution for $120 \mathrm{~min}$ to remove SDS. Finally, the gels were incubated in a developing buffer (50 mM Tris- $\mathrm{HCl}, \mathrm{pH} 7.5$, containing $5 \mathrm{mM} \mathrm{CaCl} 2,100$ $\mathrm{mM} \mathrm{NaCl}, 0.5 \mathrm{mM} \mathrm{MgCl} 2$, and $0.002 \mathrm{mM} \mathrm{ZnCl} 2$ ) at $37^{\circ} \mathrm{C}$ overnight, rinsed, and stained with Coomassie brilliant blue. Areas of gelatin digestion were visualized as non-staining regions in the gel. To determine the effects of various $\mathrm{pH}$ on $E$. coli proteolytic activity, cell-free $E$. coli $\mathrm{K} 1$ conditioned medium was electrophoresed, and gels were incubated overnight in $\mathrm{pH} 3,4,5,6,7,8,9$, and 10 (0.1 M citrate buffer was used to adjust $\mathrm{pH} 3,4$, and 5; $0.1 \mathrm{M}$ phosphate buffer was used for $\mathrm{pH} \mathrm{6,} 7$ and 8; and 0.2 M glycine buffer was used for $\mathrm{pH} 9$ and 10). Following this incubation, gels were stained with Coomassie brilliant Blue. The results are representative of three independent experiments.

For protease assays, E. coli conditioned media $(10 \mu \mathrm{L})$ were incubated with $2 \mu \mathrm{g}$ of bovine serum albumin (BSA) and rabbit IgG (rIgG) in a final volume of $20 \mu \mathrm{L}$ in incubation buffer $(50 \mathrm{mM}$ Tris- $\mathrm{Cl} \mathrm{pH} 8.0,100 \mathrm{mM}$ $\mathrm{NaCl}, 5 \mathrm{mM} \mathrm{CaCl}_{2}, 500 \mu \mathrm{M} \mathrm{MgCl}$ and $2 \mu \mathrm{M} \mathrm{ZnCl}_{2}$ ) in $0.5 \mathrm{~mL}$ eppendorf tubes. Tubes were incubated for $18 \mathrm{~h}$ at $37^{\circ} \mathrm{C}$. The BSA and rIgG in the absence of conditioned media were used as negative controls, while A. castellanii conditioned media (known to produce

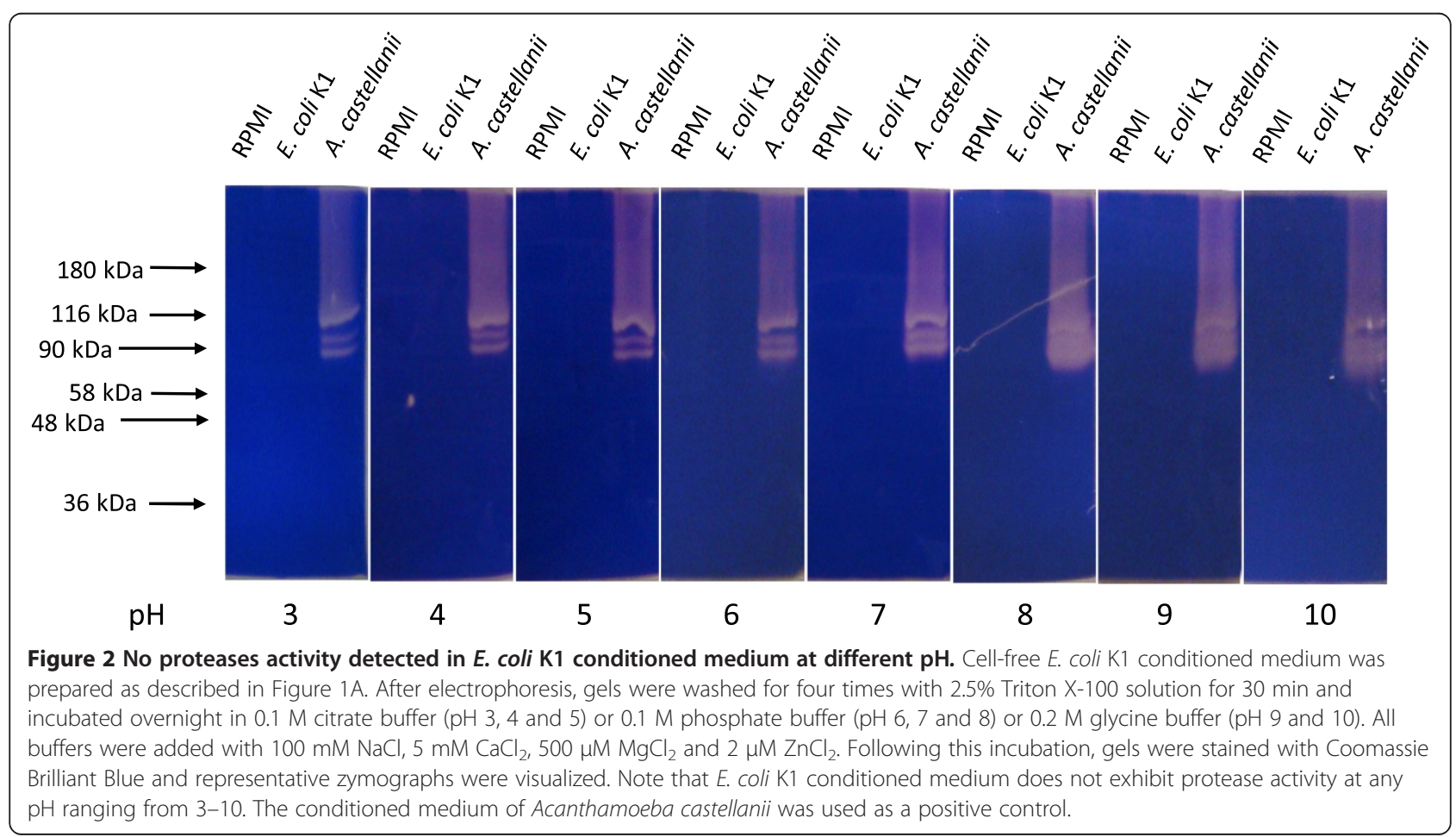


proteases) [12], were used as positive controls. Following this incubation, samples were mixed with equal volume of $2 \times$ SDS loading buffer, boiled and loaded onto $12 \%$ SDS-PAGE gel to determine BSA/rIgG degradation. After electrophoresis gels were stained with Coomassie Brilliant Blue and visualized. The results are representative of three independent experiments.

\section{Results and discussion}

To determine the proteolytic activities of $E$. coli whole cells lysates or their conditioned media, zymographic assays were performed. The lysates of $A$. castellanii (positive control) exhibited gelatin degradation (Figure 1A); however, neither $E$. coli $\mathrm{K} 1$ strain $\mathrm{E} 44$ lysates nor $E$. coli K-12 strain HB101 tested, showed gelatin degradation in zymographic assays (Figure 1A). Similarly, the conditioned medium of $E$. coli did not exhibit gelatin or collagen degradation in zymographic assays (Figure $1 \mathrm{~B}$ and 1C). As expected, serum alone exhibited proteolytic activities (Figure $1 \mathrm{~B}$ and $1 \mathrm{C}$ ). The conditioned medium prepared in the presence of $10 \%$ foetal calf serum did not show any additional noticeable protease band on zymograms (Figure $1 \mathrm{~B}$ and $1 \mathrm{C}$ ). When higher percentages zymography gels (10\% and $12 \%)$ were used to detect low molecular mass protease(s), no additional protease bands on zymograms were observed (data not shown). When tested under various $\mathrm{pH}$, the results revealed that $E$. coli K1 conditioned medium does not exhibit protease activity at any $\mathrm{pH}$ ranging from 3-10 (Figure 2).

Furthermore, E. coli K1 proteases did not exhibit substrate specificity as no proteolytic activity was observed on gelatin or collagen substrate SDS-PAGE gels. To determine whether assay conditions may have affected extracellular proteases of $E$. coli, protease assays were performed by incubating conditioned medium with BSA and rIgG, followed by electrophoresis on SDS-PAGE gels. The findings revealed that the conditioned medium of neither $E$. coli $\mathrm{K} 1$ nor $E$. coli $\mathrm{K}-12$ had any effect on the degradation of BSA and rIgG. Conversely, the conditioned medium of $A$. castellanii (known to possess a number of proteases) [12] degraded both of these substrate proteins completely (Figure 3). Similar results were observed when human secretary IgA was used as a substrate in the protease assays (data not shown).

The proteolytic enzymes have been identified as virulence factors in various bacterial pathogens including Vibrio vulnificus [13], Pseudomonas aeruginosa [14], Staphylococcus aureus [15], Porphyromonas gingivalis [16], and their role as therapeutic target is under intense investigations. Given the role of proteases as protein quality control machinery as well as controlled proteolysis of regulatory proteins, highlights their involvement in bacterial viability and virulence. For example, Clp protease complexes play a vital role in regulating virulence
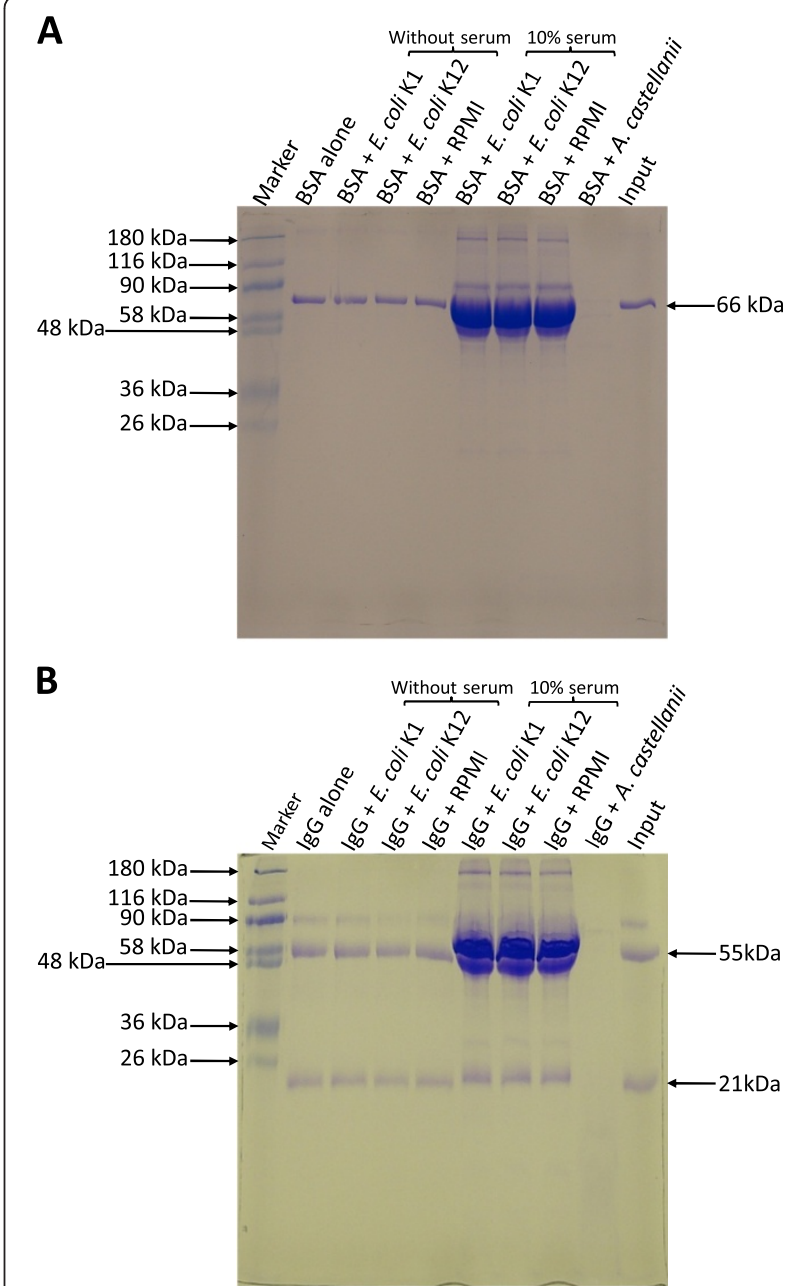

Figure 3 E. coli $\mathrm{K} 1$ did not affect degradation of bovine serum albumin (BSA) and rabbit immunoglobulin $\mathrm{G}(\mathrm{rlg} \mathrm{G})$ in protease assays. The conditioned medium of E. coli K1 strain E44, E. coli K-12 strain HB101 and A. castellanii was prepared as described in Materials and Methods. The conditioned media were incubated with $2 \mu \mathrm{g}$ of BSA (A) and rlgG (B) overnight in incubation buffer $(50 \mathrm{mM}$ Tris-Cl $\mathrm{pH}$ 8.0, $100 \mathrm{mM} \mathrm{NaCl}, 5 \mathrm{mM} \mathrm{CaCl}, 500 \mu \mathrm{M} \mathrm{MgCl}_{2}$ and $2 \mu \mathrm{M} \mathrm{ZnCl}_{2}$ ) at $37^{\circ} \mathrm{C}$. Next day, an equal volume of $2 \times \mathrm{SDS}$ sample loading buffer was added in all samples, boiled and loaded onto 12\% SDS-PAGE gel. After electrophoresis gels were stained with Coomassie Brilliant Blue and visualized. Note that bacterial conditioned media did not degrade BSA/rlgG in protease assays tested. The results are representative of three independent experiments.

factor(s) production in Gram-positive bacteria, while conserved proteases of Gram negative bacteria impacting biological processes across the bacterial envelope affecting bacterial viability and pathogenesis [4]. Genomic analysis of $E$. coli $\mathrm{K}-12$ revealed that it encodes for more than 70 proteases [17] and studies have reported the presence of cellular and secreted proteases from different $E$. coli strains $[18,19]$ but under the assays employed and the experimental conditions tested, no proteases were detected in either neuropathogenic E. coli 
K1 strain E44 or E. coli K-12 laboratory strain HB101, tested in the present study. In addition to strain differences, a likely explanation of these contradictory findings is that the proteolytic activity is inducible (expressed in response to milk proteins or other environmental conditions) and limited constitutive proteases. Future studies are needed to grow E. coli K1 under a variety of conditions including different oxygen tensions, heat shock conditions as well as in the presence of different host cells to establish extracellular proteolytic activities of neuropathogenic E. coli $\mathrm{K} 1$.

\section{Competing interests}

The authors declare that they have no competing interests.

\section{Authors' contributions}

NK conceived the study. JI and RS designed and conducted all experiments under the supervision of NAK. RS, J, MK and NAK contributed to the writing of the manuscript. All authors approved the final manuscript.

\section{Acknowledgements}

This work was supported by grants from the Aga Khan University.

\section{Author details}

'Department of Biological and Biomedical Sciences, Aga Khan University, Karachi, Pakistan. ${ }^{2}$ Dow Medical College, Dow University of Health Sciences, Karachi, Pakistan

Received: 5 March 2013 Accepted: 11 April 2013

Published: 1 May 2013

\section{References}

1. Barrett AJ, Rawlings ND, Woessner JF: Handbook of proteolytic enzymes. 2nd edition. Amsterdam; Boston: Elsvier Academic Press; 2004. 2 v. (xxxv, 2140 p.).

2. Dolly JO, Aoki KR: The structure and mode of action of different botulinum toxins. Eur J Neurol 2006, 13(Suppl 4):1-9.

3. Young JA, Collier RJ: Anthrax toxin: receptor binding, internalization, pore formation, and translocation. Annu Rev Biochem 2007, 76:243-65.

4. Ingmer $\mathrm{H}$, Brondsted L: Proteases in bacterial pathogenesis. Res Microbiol 2009, 160(9):704-710.

5. de Louvois J, Blackbourn J, Hurley R, Harvey D: Infantile meningitis in England and Wales: a two year study. Arch Dis Child 1991, 66(5):603-607.

6. Dietzman DE, Fischer GW, Schoenknecht FD: Neonatal Escherichia coli septicemia-bacterial counts in blood. J Pediatr 1974, 85(1):128-130.

7. Gladstone IM, Ehrenkranz RA, Edberg SC, Baltimore RS: A ten-year review of neonatal sepsis and comparison with the previous fifty-year experience. Pediatr Infect Dis J 1990, 9(11):819-825.

8. Unhanand M, Mustafa MM, McCracken GH Jr, Nelson JD: Gram-negative enteric bacillary meningitis: a twenty-one-year experience. J Pediatr 1993, 122(1):15-21.

9. Kim KS: Current concepts on the pathogenesis of Escherichia coli meningitis: implications for therapy and prevention. Curr Opin Infect Dis 2012, 25(3):273-278.

10. Mukherjee DV, Tonry JH, Kim KS, Ramarao N, Popova TG, Bailey C, Popov S, Chung MC: Bacillus anthracis protease InhA increases blood-brain barrier permeability and contributes to cerebral hemorrhages. PLoS One 2011, 6(3):e17921.

11. Huang SH, Wass C, Fu Q, Prasadarao NV, Stins M, Kim KS: Escherichia coli invasion of brain microvascular endothelial cells in vitro and in vivo: molecular cloning and characterization of invasion gene ibe10. Infect Immun 1995, 63:4470-4475.

12. Dudley R, Alsam S, Khan NA: The role of proteases in the differentiation of Acanthamoeba castellanii. FEMS Microbiol Lett 2008, 286(1):9-15.

13. Miyoshi N, Shimizu C, Miyoshi S, Shinoda S: Purification and characterization of Vibrio vulnificus protease. Microbiol Immunol 1987, 31:13-25.

14. Wretlind B, Pavlovskis OR: Pseudomonas aeruginosa elastase and its role in pseudomonas infections. Rev Infect Dis 1983, 5(5):S998-1004.
15. Smagur J, Guzik K, Magiera L, Bzowska M, Gruca M, Thøgersen IB, Enghild JJ, Potempa J: A new pathway of staphylococcal pathogenesis: apoptosislike death induced by staphopain $B$ in human neutrophils and monocytes. J Innate Immun 2009, 1:98-108.

16. Fitzpatrick RE, Aprico A, Wijeyewickrema LC, Pagel CN, Wong DM, Potempa J, Mackie EJ, Pike RN: High molecular weight gingipains from Porphyromonas gingivalis induce cytokine responses from human macrophage-like cells via a nonproteolytic mechanism. J Innate Immun 2009, 1:109-117.

17. Ehrmann M: E. coli protease database. http://www.cf.ac.uk/biosi/staffinfo/ ehrmann/tools/proteases/allproteases.html.

18. Haddadi KK, Moussaoui FF, Hebia II, Laurent FF, Le Roux YY: E. coli proteolytic activity in milk and casein breakdown. Reprod Nutr Dev 2005, 45(4):485-496.

19. Gottesman S: Proteases and their targets in Escherichia coli. Annu Rev Genet 1996, 30:465-506.

doi:10.1186/1477-5751-12-8

Cite this article as: Iqbal et al: Neuropathogenic Escherichia coli K1 does not exhibit proteolytic activities to exert its pathogenicity. Journal of Negative Results in BioMedicine 2013 12:8.

\section{Submit your next manuscript to BioMed Central and take full advantage of:}

- Convenient online submission

- Thorough peer review

- No space constraints or color figure charges

- Immediate publication on acceptance

- Inclusion in PubMed, CAS, Scopus and Google Scholar

- Research which is freely available for redistribution 